\title{
Facilitating Teaching Strategies and Active Learning in Greek Early Years Department Students
}

\author{
Eleni Tympa \\ Department of Early Years Learning \& Care, University of Ioannina \\ $4^{\text {th }}$ Klm National Rd Ioannina, Athens, 45500, Ioannina, Greece \\ Tel: 30-265-105-0738Ｅ-mail: etimpa@uoi.gr \\ Vasiliki Karavida \\ Department of Early Years Learning \& Care, University of Ioannina \\ 4th Klm National Rd Ioannina, Athens, 45500, Ioannina, Greece \\ Tel: 30-265-105-0738Ｅ-mail: vkar@uoi.gr \\ Vasiliki Filippa \\ Department of Early Years Learning \& Care, University of Ioannina \\ 4th Klm National Rd Ioannina, Athens, 45500, Ioannina, Greece \\ Tel: 30-265-105-0738Ｅ-mail: vasokisspa22@gmail.com
}

Received: June 6, 2021 Accepted: August 10, 2021 Published: August 17, 2021

doi:10.5296/jei.v7i2.18845 URL: https://doi.org/10.5296/jei.v7i2.18845

\begin{abstract}
The aim of the study was to examine whether participation of academic students in experiential activities during their semester lessons could facilitate their learning and improve their exam performance. The study involved 68 students of an Early Years Learning \& Care Department, who volunteered and committed to attend all semester lessons. All students participated actively during the lessons. At the end of the semester students were interviewed with a semi-structured protocol on the experiences of the teaching process and on what they thought the impact of the process will be on written exams. Participants had been informed of the purposes of the study in advance, they had the right to withdraw at any time and anonymity was guaranteed. All students stated that they enjoyed the process, preferred it to a
\end{abstract}


passive lecture, gained more knowledge and were more prepared for the exams. This interactive teaching process concerns both university teachers and students, requires planning and merits further discussion.

Keywords: Students, Communication, Teaching strategies, Active learning, Early years

\section{Introduction}

Communication can be represented as the process by which beliefs, information, opinions, knowledge and feelings are expressed from one person to another. The communicator or sender is someone who establishes communication by sending a message. The receiver is the one who completes the communication by receiving the message and reacting to it (Duta, 2015). The message can be communicated through different ways; linguistic (content, meaning, speech qualities) and non-linguistic (body language, body contact, distance, appearance etc). Communication is a two-way process in which both communicator and receiver participate at the same time. The communicator knows how successfully his message is communicated through the receiver's feedback (Genc, 2017).

The continuous exchange of messages contributes to the relative homogeneity of groups, as people start sharing common ambitions, convictions, aspirations and knowledge, they start developing intellectual and emotional similarities and comparable ways to respond to expectations and requests. Communication thus constitutes an absolutely necessary element and vital skill for almost any line of work, especially for educators, in teacher-student relationships (Iurea, 2015; Duta, 2015). It is known that we owe our thinking and interacting skills in groups and our role in social relations to communication. People spent about $75 \%$ of their active time on verbal communication. This means that we either discourse or listen for 12 hours a day on average. Additionally, $60 \%$ of this communication period is spent on listening, and $40 \%$ of it is spent on talking (Yilmaz, 2017).

\subsection{Active Learning in University Students' Education-Students' Relationship and Engagement}

Interactive approach is highlighted as a learning methology that focuses on the activity inside the classroom itself and uses a combination of approaches, practises and strategies (Philips, 2005; Gleason et al., 2011). Mabrouk (2007) presented a basic description for active learning as a teaching technique that actively engage students in the classroom. Active learning approaches are utilized within the classroom to neutralise passive learning, such as a lecture, in which the teacher is usually the most active member. If students are directly interacting (not just listening) with one another or with a teacher, the pedagogy employed is considered as active learning (McCarthy \& Anderson, 2000). Active learning encourages personal motivation, construction of strategic learning behavior, improves deep understanding, development of critical thinking, self-directed learning, and provides students with multiple opportunities to self-assess and reconsider their own thinking processes to better solve problems (Mpakirtzis, 2012). In addition, active learning techniques promote student engagement by holding them accountable for involvement through specific question and response techniques, cooperative learning groups, and partner discussion, which empowers 
students to move from passive learning into active learning; a method which requires participation, cooperation and communication between both the students and the teacher, as well as peers between them (Conner, 2016).

Students take an active role in learning by reading, writing, analysing, debating, determine and creating so as to practice high-class thinking skills (Ott et al., 2018). However, in collaborative learning, students take part in significance and knowledge-building as well as learn skills through cooperation and communication (Ralston et al., 2017; Zheng et al., 2014).

Learning experiences and teaching practices affect further decisions and support students' continuing lifelong learning. Many researchers have studied the ways that students learn and improve skills better in order to improve education and engagement (Slavich \& Zimbardo, 2012). Teachers and students who share the qualities of successful communication and respect in the classroom; who both show interest in educating and learning from their perspective, will establish a positive relationship in the classroom. Communication is a crucial element in the teaching-learning process (Duta, 2015). According to Liberante (2012) "The teacher-student relationship is one of the most powerful elements within the learning environment. A major factor affecting students' development, school engagement and academic motivation; teacher-student relationships form the basis of the social context in which learning takes place".

In addition to the above, Fenn (2014) claims that it is a necessity, that the process of communication is mutually understood by the teacher and the student so as to ensure the effectiveness of the teaching-learning process. Teachers constantly convey new knowledge or information to students but also want them to be motivated, enthusiastic and engaged.

Academic, cognitive, intellectual, emotional, behavioral, social and psychological are some of the sub-categories, students can engage in. Committed students are attentive and take part in classroom discourses, are diligent in classroom activities and show great engagement and motivation to learn. What is more, they are inquisitive and exchange ideas and leading roles. In their classrooms, teachers can easily determine the extent to which concepts and topics are comprehended by students so that they can further explain and discuss when necessary. In those classrooms, in which students' involvement is more active, there is more energy, which is also passed on to students' peers and teachers (Havik \& Westergard, 2020; Handa, 2020). Committed students working in groups do not stop discussing, asking each other and their teachers questions, listening with interest to each and every one and arguing with examples drawn from personal experience and knowledge.

\subsection{Teachers' Capacity on Active Learning}

Teachers with good communication skills always make things easier, more experiential and more comprehensible for the students. Effective communication skills are really important for a teacher in imparting knowledge, classroom management and cooperation with students in the classroom (Khan et al., 2017). Engaging students in conversations about curricular decisions and questions of learning, invites them to the backstage of education and provides a great opportunity to participate and be part of the curriculum. Dialogue provides valuable 
insight for teachers, and a willingness for students to make decisions together and interact, harnessing the creativity and varying perspectives of both students and teachers (Matthews, 2016).

The teacher-student relationships is a regulatory function for the growth of social, emotional, and academic skills of the students. Studies have shown that good teacher-student relationships create a positive atmosphere in the classroom that promotes successful school adjustment and thus increases students' motivation to learn. On the contrary teacher-student confrontations are associated with low self-esteem and academic performance, as well as with continuing relative conflict with teachers and students (Koca, 2016).

Promoting an alternative educational approach that focuses mainly on learning and training, could lead to the implementation of communication practices in the classroom and further stimulate students' interest by facilitating the learning process. This is especially determinant when the educator-student relationship and teaching-learning process are being limited; the educator is more of a mediator and it is the student who constructs his or her own lifelong learning process (Funtes et al., 2017).

Mpakirtzis (2012) highlighted the importance of experience, emotion and communication in the learning process. The experience of emotion in a learning context is associated with active participation, research, discovery, creative dialogue, recognition and acceptance of emotions. It is worth noting that in such a context learning is based on cultivating the relationship and interaction of knowledge and emotions, as a friendly, supportive, but not stressful learning environment is created, in which the student has the opportunity to actively participate in each phase and co-shape it (Sánchez-Martin et al., 2018).

Researchers have taken into consideration the significance of creating active and learning environments. Niemi (2002) explored the opportunities pre-service teachers are given in practicing active learning during their teaching. Much as encouraged active learning is in primary and secondary schools, direct teaching is occasionally applied in university classrooms as a primordial type of content delivery (Williams, 2008). Williams' suggestion was that innovative and commendable practice should be implemented in teacher education programs so as to promote adopting active learning. It is evident in previous literature that teachers teach the way they were taught (Parsons, 2005). Thus, active learning, being used by pre-service teachers during their education, is crucial in their capacity to implement active learning effectively as teachers (Sahin-Taskin, 2018).

\section{Method}

\subsection{Research Goal}

The present study asks how students in higher education perceive active learning and participation in the classroom during their lessons. It also aims to look at whether early year university students can use playful learning skills while engaged in experiential activities during their semester lessons and how they could advance their learning and upgrade their performance in exams. 
Qualitative research designs have the capacity to focus on substantial robust data to uncover the many reasons that teachers may prefer to teach the way they do and advance the field of playful learning (Taylor \& Wallace, 2007).

Data for this study came from the Department of Early Years Learning and Care of the University of Ioannina in West Greece. In the present study, a participatory research approach was occupied with focus groups, which gave the participants the opportunity to create a shared understanding of the benefits of communicative and participating learning as a way of teaching and to study the benefits of this teaching method which has not been clearly defined yet (Rabiee, 2014; Nyumba et al., 2018). Data were gathered through dialogic interviews, semi-structure interviews (conducted in the university campus at a time convenient for the academic students and quotes were anonymised) and through the researcher's field notes. It is essential to note that this was an exploratory study that delineated what happens when academic students participate in the teaching processes and whether it facilitated the acquisition of the learning skills during their lessons (La Lopa et al., 2018; Tracy, 2013). Thus, it is expected that this may provide a significant insight into such teaching situations. This exploration became at the same time the tool for data collection to address the needs of this research project and the means to explore the answers to the study's research questions. The study indicated the following research questions:

Research Question 1: Can students from an early years department use their playful learning skills to participate and communicate with their peers during the theoretical lessons they participate.

Research Question 2: Can communicative and interaction activities facilitate students' learning during their lessons in higher education?

Research Question 3: Can the student-teacher relationship affect students' performance during the exams and what are the students' expectations for their grade?

\subsection{Sample and Data Collection}

To understand how students view participating learning and how participating activities facilitate their learning skills, the research team interviewed 68 Early Years academic students, 45 (out of 110) of the first semester and 23 (out of 83) of the fifth, who volunteered and committed to attend all the semester lessons, although they were not obligatory. All students were females. The students engaged in actively during the lesson with presentations, musical games, role plays and group work. At the end of the semester the students were interviewed with the use of a semi-structured interview schedule on their experiences and thoughts of the teaching process, as well as the views on the potential impact of this teaching/learning process on their written exams.

\subsection{Procedure}

Those who decided to take part in the study, committed in principle to attend all the courses of the semester. The students of the first semester committed to the course Health Education while the students of the fifth semester committed to the course Child Education. After their 
written agreement, they decided together with the researcher to plan the courses for the whole semester. Role-playing games, storytelling, group discussions, music-movement games were designed for each thematic unit.

At the end of the semester all participant academic students were invited to the interviews in groups of 2 or 3 . The grading in the written exams of the semester was done with a blind assessment so that the researcher was not influenced by the names of the participants in the research.

\subsection{Analysing of Data}

The researchers used abductive reasoning when coding the data. They started with placing the general position (Higher education practices in general) to arrive at a more specific one (active learning and participation in the teaching process). Timmermans and Tavory (2012), express that abduction, rather than induction, logically lead to novel theoretical insights and applies to a creative deductive process aimed at generating new hypotheses and theories based on amazingly research evidence. In this research general aspects related to higher education and students' concerns were used to help them develop their views and reach specific aspects, as emerged from the interviews.

\subsection{Ethical Issues}

Participants had been informed in advance of the purposes of the study and gave written concern for their participation. Their identity has been protected as data presented was anonymized and they had the right to retreat at any time.

\section{Results}

Most of the students declared that they enjoyed the process, preferred it to a typical and passive lecture, gained more knowledge and were more qualified for the exams. Regarding the outcome of the exams $84 \%$ of them had a much better test score (on average a grade 8 out of 10).

Data analysed from the students' interviews highlighted four general themes on their comprehension of active learning: (1) pedagogical engagement, (2) relevance and skills-building, (3) student motivation and participation, and (4) practical challenges for implementation.

\subsection{Educational Commitment}

When students asked how they perceived participatory and communicative learning, they referred to in-class and out-of-class activities that could facilitate course study and exams' outcome. Many expressed the need for participation in the process of the lectures and for interactive activities during the lessons so as not to get bored. Many thought that the games they have already learnt during their studies could be useful for other theoretical lessons. Others believed that such activities are useful for teaching in the classroom with young children. Experiential learning also enhances creativity and problem solving.

A sample of students' quotes highlighting these points follows: 
Student 1: Lectures by professors are definitely useful and often necessary. However, I believe that students should also be given the chance to enter the process of lectures, preparation and presentation, so that they gain experience and do not stress when they have to teach on their own in the classroom.

Student 2: Why do I need to come to the class if the teacher just teaches that it already exists in the book, which I can have from the beginning of the semester? The teacher must inspire me with something different to listen to him and follow him.

Student 3: When teaching is teacher-centered I get bored. I'm just in the classroom without listening.

Student 4: Interactive teaching may not be necessary for some schools. However, for us as pedagogical students, I believe that playful learning is imperative, because we will use it when we enter the classroom ourselves and stand in front of young children.

\subsection{Skills-Development and Relevance}

In addition to the way of teaching, students are interested in acquiring skills that will lead them to new knowledge and practical application and promote language and expressive skills. For this reason, the content of the course should be attractive and help them visualize the theory, understand it and put it into practice. Furthermore, the teacher should be able to promote communicative teaching and be a good mentor. Most people think that university paves the way for student's professional life, so the courses should be based on case studies and practical activities.

A sample of students' quotes highlighting these points follows:

Student 1: I consider it is a very important skill to conquer speech and its free speech without being afraid of being censored even by young children. My participation in such a learning process promotes my language and expressive skills.

Student 2: The transmission of knowledge and the organization of experiential activities has to do with the pedagogical skills of the teacher. I believe that not all teachers are able to promote a communicative teaching.

Student 3: Through such practices I believe that I strengthen my character and my personality and acquire skills that are useful to me in my personal life.

Student 4: The acquisition of skills within the course reinforces critical thinking, which is necessary not only for the profession, but also outside it, e.g., in our personal relationships and relationships with our fellow students.

Student 5: The teacher who is interested in communication learning I think should be a good mentor. To cite examples from his personal life, I personally would prefer his failures, something that gives us strength and new skills to face possible failures in the future.

\subsection{Student Participation and Motivation}

Another topic that emerged from the interviews was how encouragement and participation 
are important factors for learning. Most students agree that active learning is based on the premise that students are interested, motivated, and involved in the classroom. They believe that the responsibility falls on them to the same extent as on the teachers. "Students cannot expect teachers to be good at what they do if they themselves do not cooperate in the classroom." However, many are concerned that they could be considered by their peers as too devoted.

A sample of students' quotes highlighting these points follows:

Student 1: In order to participate in the class, I believe that I need to have more motivation, such as being evaluated for my participation and including this in my final grade.

Student 2: (Answer to the above): but this way we will never participate for our own development, we will always be guided by the score. I do not know if this makes our participation meaningful.

Student 3: Many times, I want to attend the class but I see the indifference of my fellow students and I get carried away so as not to be considered too devoted (nerd). Do I finally have to think about the role of the fellowship in the outcome of my studies?

Student 4: I wonder if in the end the teacher should be more determined than us and address the speech directly to me and not to the whole class.

\subsection{Challenges for Implementation}

To implement all of the above, it is widely accepted that there are some practical challenges. The time, the preparation of the students for this learning model from the beginning of their studies as well as the number of students and the space are some of them. There is a challenge for teachers to find a balance between students who prefer interactive lessons and those who prefer to sit and take notes. In view of this, teachers discuss about the students' lack of attention and the need to involve them in more participating process. Diversely, some students expressed the view that they feel unfamiliar, uncomfortable and not fitted out to fully participate in such a process.

A sample of students' quotes highlighting these points follows:

Student 1: I believe that especially in the pedagogical directions the space should be more suitable for playful learning. The classrooms with the seats as they are shaped do not allow movement and play even in a short form.

Student 2: With this way of teaching things go slower. How will the course material be covered when more time is devoted to interactive discussion or interactive activities? Do we need to think of a mixed teaching model? On the other hand, I do not know how provocative this will be for the students. I imagine that most of them come only to interactive lessons and not to all lectures.

Student 3: We must also think about the side of students who due to introversion or lack of self-confidence do not want to take part in experiential games. For example, I prefer to listen and take notes. 


\section{Mll Macrothink}

\subsection{Exams' Outcome}

Following the exams and according to the blind assessment of each course, the grades showed that the students who participated in this teaching approach had better performance and better grades. The students expressed the expectation for higher grades in the course and the desire to apply to other courses. Interestingly enough, as shown in Figure 1, out of the 68 students who participated, $84 \%$ got a grade of $8-10$. Of the remaining 125 in both courses, only $11.2 \%$ reached this grade.

A sample of students' quotes highlighting these points follows:

Student 1: I initially decided to participate to improve my score, but in the process, I found out that I acquired new skills.

Student 2: I would like other teachers to follow the approach and to my fellow-students to grab such opportunities and not only for grade.

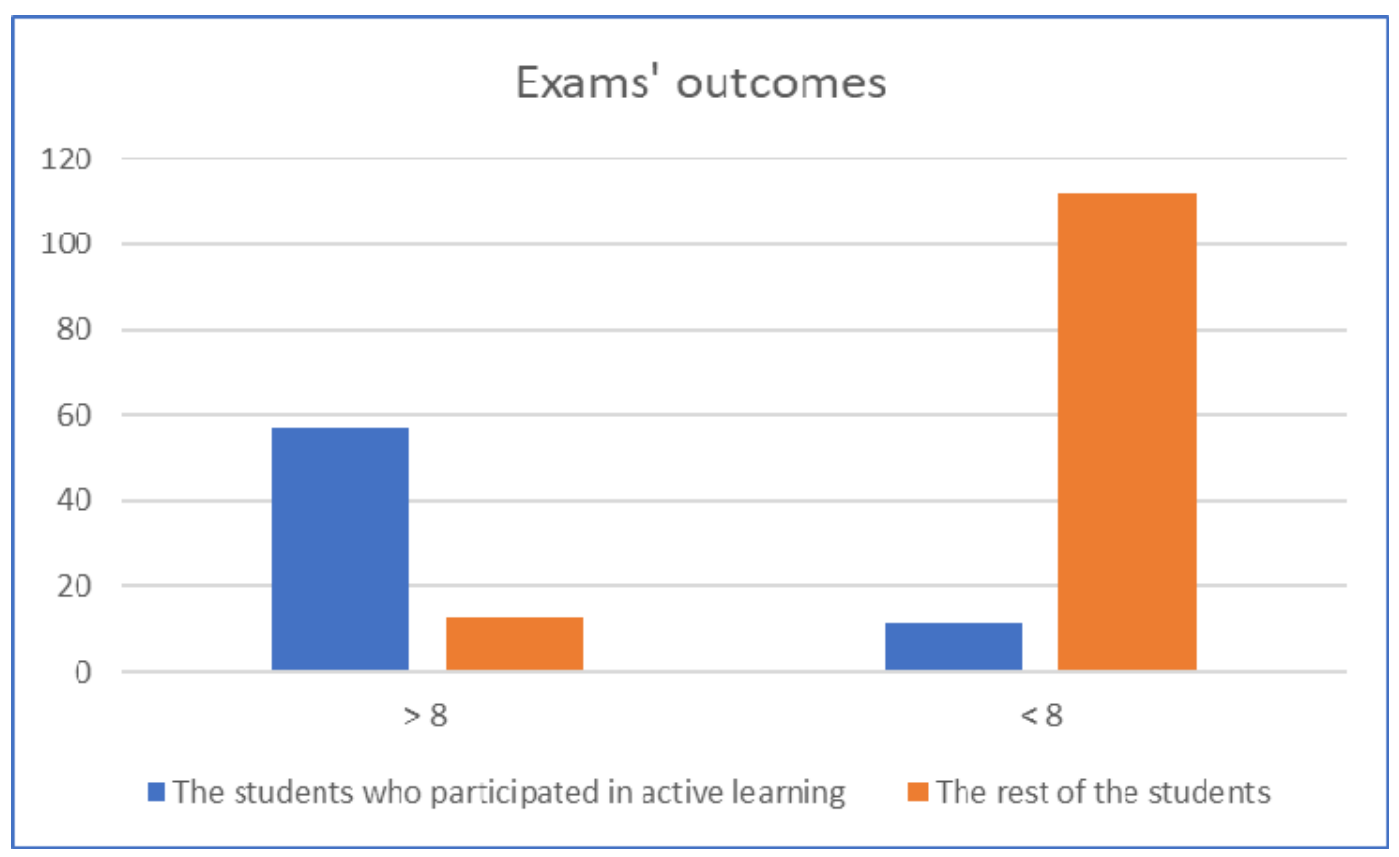

Figure 1. Students' outcomes at the end of the semester

\section{Discussion}

The aim of this study was to understand students' perspective on participating in learning and interaction activities during the lessons, and how this affects or facilitates their learning skills and performance. Throughout the semester, students participated in the course through various activities, designed for thematic units by both the researcher and the students, such as role-playing games, group discussions, storytelling and music-movement games. At the end of the semester the participating students were interviewed in small groups. 


\section{$\Lambda$ Macrothink}

The results of the current study contribute to the understanding of the importance of students' communication and participation existence in Higher Education. Engaging pedagogy and engaging curriculum were the two aspects that seem to encourage engagement (Taylor \& Parsons, 2011). Study results have shown that both experiential learning and interactive teaching and activities, enhance creativity in students and offer them the opportunity to enter the process of lectures and therefore gain more experiences because academic students from an Early Years Department learn new strategies that can be used in their future professional life. This issue means that the innovations promoted within the university have a multiplier effect, because they can affect future generations (Zamora-Polo et al., 2019). When a teacher affords students with knowledge and advice, in addition to the information offered in any course book, the students will be inspired and will use this knowledge to their advantage, while at the same time they will not get bored during a lecture that will be teacher-centered. Education revision movements in Greece and around the world have demanded that educators deviate from traditional passive learning and turn to constructive learning. However, research has shown that educators need more training to use constructivism in the teaching-learning process (Tanwar, 2015).

Similarly, it has been stated in various studies that working with authentic or community problems attracts students and builds a sense of purpose in the learning experience; students want their work to be mentally appealing and relevant to their lives (Taylor \& Parsons, 2011).

Most of the students who took part in the current study, thought that the content of the course should be attractive, based on case studies and practical activities. Participating in an interactive lesson and problem-based learning, gave the students the opportunity to promote their expressive skills, strengthen their character and also helped them to acquire critical thinking (Ulger, 2018).

In addition to the above, the teacher should be a good communicative mentor, who effectively manages to impart his knowledge. Ambrosetti and Dekkers (2010) add that mentoring is vital to improving students' learning opportunities in real-world or real-world contexts. This learning is carried out effectively through modeling and observations during the course, critical and constructive evaluation of the course, providing and discussing feedback, group teaching, counseling and role modeling, critical friendship and equal collaboration (Mukeredzi, 2017). Based on the "Common European Framework of Reference for Languages: Learning, teaching, assessment" by the Council of Europe (2001), the development of communication skills depends on linguistic, speech, socio-cultural and sociolinguistic knowledge, skills and personal assessments that confirm a person's entry into another society and contribute to his socialization in a foreign environment.

According to Taylor and Parsons (2011), respectful relationships and interaction are shown to improve student engagement. Open, caring and respectful relationships between students and educators are important for the development and support of social and psychological participation in learning. Creating an engaging learning environment involves ensuring that students feel able and secure to challenge teachers as part of the learning process. It also means that students need to learn interpersonal skills to engage in dialogue with respect and 
constructiveness, as well as to learn the content of the topic (Jõgi et al., 2015). In order to achieve such a learning environment, students should be interested in the lesson, motivated and involved, as stated by them during the research interviews. As expected, not all the students have the same opinion about participation in lessons. Some commented that they would like to be evaluated for their participation, in the final grade, while others believe that in this case, grades will be the only motivation, not the motivation to learn. Finally, there are some students who are afraid of being considered too devoted or called 'nerds' because of their interest and participation in the lesson (Al-Samarraie \& Hurmuzan, 2018).

The results of the research offered various students' views on the application of interactive and participating learning. The greatest difficulty of applying this type of learning, concerns the students who, due to their character and lack of self-confidence, do not feel comfortable and familiar about being exposed, and prefer to sit and take notes during the lesson. This challenge must be addressed by teachers, by balancing lessons between these two extremes. This is the first practical difficulty of implementing participation (McPartland, 2018).

Other practical difficulties are space, time and preparation of the students. Usually, the space in the existing available classrooms, where students could move about during the activities, is limited, as the classrooms are filled with chairs and desks. Flexible classrooms are needed to support active learning through portable tables and chairs that can be repositioned into different configurations. Active learning models, such as peer discussions during class, problem solving individually or in groups, hands-on activities, or engagement in problem-based learning, have been proven to expansion students' retention of information, conceptual understanding, self-esteem, and attitudes about their studies (Freeman et al., 2014; Johnson et al., 2020).

Also, the implementation of the participating and interactive learning is time consuming, causing concern to students about the cover of course material and preparation for the final exams (Trinidad, 2020).

Finally, the exam outcome of the present study indicates that the majority of the participating students performed better and achieved higher grades, which shows us the positive effect of both continuous attendance in all the semester lessons and active participation in them, with displays, musical games, role plays and group work. Overall, active participation and games have a moderate beneficial effect on student performance, knowledge, abilities, and engagement (Murillo-Zamorano et al., 2019; Strelan et al., 2020).

\section{Conclusion}

In conclusion, according to the students' quotes, most of them showed willingness and interest to attend and take part in a much more interactive way of teaching, which offers more opportunities to participate and communicate in the class, while others expressed concern that this process would cost the course material coverage. There are doubts about the effectiveness of it as a teaching strategy, especially about the way teachers can manage and implement it in an effort to include in the teaching process students, who prefer a more passive way of teaching that will involve less of their own participation. 


\section{Recommendations}

Active learning could be applied to more areas of the curriculum and involve a larger number of students. More and larger university spaces could also be utilized to facilitate active learning.

\section{References}

Al-Samarraie, H., \& Shuhaila, H. (2018). A review of brainstorming techniques in higher education. Thinking Skills and Creativity, 27, 78-91. https://doi.org/10.1016/j.tsc.2017. 12.002

Ambrosetti, A., \& Dekkers, J. (2010). The interconnectedness of the roles of mentors and mentees in pre-service Teacher Education mentoring relationships. Australian Journal of Teacher Education, 35(6), 42-55. https://doi.org/10.14221/ajte.2010v35n6.3

Conner, T. (2016). Relationships: The Key to Student Engagement. International Journal of Education and Learning, 5(1), 13-22. https://doi.org/10.14257/ijel.2016.5.1.02

Council of Europe. (2001). Common European Framework of Reference for Languages: Learning, Teaching, Assessment. Cambridge University Press, UK.

Duta, N. (2015). From theory to practice: The barriers to efficient communication in teacher-student relationship. Procedia-Social and Behavioral Sciences, 187, 625-630. https://doi.org/10.1016/j.sbspro.2015.03.116

Fenn, V. (2014). Effective Communication Skills in Teaching-Learning Process. Grammar and Grammar Teaching: Changing Perspectives, 2(14), 53-57.

Freeman, S., Eddy, S. L., McDonough, M., Smith, M. K., Okoroafor, N., Jordt, H., \& Wenderoth, M. P. (2014). Active Learning Increases Student Performance in Science, Engineering, and Mathematics. Proceedings of the National Academy of Sciences, 111(23), 8410-8415. https://doi.org/10.1073/pnas.1319030111

Funtes, A. V. R., Blanco, M. F. A., Ortega, J. L. G., \& Perez, I. A. G. (2017). The Communication Skills of Future Teachers during their Initial Training. Multidisciplinary Journal of Educational Research, 7(1), 88-118. https://doi.org/10.17583/remie.2017. 2200

Genc, R. (2017). The Importance of Communication in Sustainability \& Sustainable Strategies. Procedia Manufacturing, 8, 511-516. https://doi.org/10.1016/j.promfg.2017.02.065

Gleason, B. L., Peeters, M. J., Resman-Targoff, B. H., Karr, S., McBane, S., Kelley, K., ... Denetclaw, T. H. (2011). Reviews: An active-learning strategies primer for achieving ability-based educational outcomes. American Journal of Pharmaceutical Education, 75(9), 186. https://doi.org/10.5688/ajpe759186

Handa, M. C. (2020). Examining Students' and Teachers' Perceptions of Differentiated Practices, Student Engagement, and Teacher Qualities. Journal of Advanced Academics, 31(4), 530-56. https://doi.org/10.1177/1932202X20931457 
Havik, T., \& Westergard, E. (2020). Do Teachers Matter? Students' Perceptions of Classroom: Interactions and Student Engagement. Scandinavian Journal of Educational Research, 64(4), 488-507. https://doi.org/10.1080/00313831.2019.1577754

Iurea, C. (2015). Classroom Environment between Stimulation and Discouragement. Teacher's Contribution to Creating a New Socio-affective Environment Favoring the Teacher-Student Communication. Procedia-Social and Behavioral Sciences, 203, 367-373. https://doi.org/10.1016/j.sbspro.2015.08.310

Jõgi, L., Karu, K., \& Krabi, K. (2015). Rethinking teaching and teaching practice at university in a lifelong learning context. International Review of Education, 61(1), 61-77. https://doi.org/10.1007/s11159-015-9467-z

Johnson, A. W., Su, M. P., Blackburn, M. W., \& Finelli, C. J. (2020). Instructor use of a flexible classroom to facilitate active learning in undergraduate engineering courses. European Journal of Engineering Education, 46(4), 618-635. https://doi.org/10.1080/03043797. 2020.1865878

Khan, A., Khan, S., Zia-Ul-Islam, S., \& Khan, M. (2017). Communication Skills of a Teacher and Its Role in the Development of the Students' Academic Success. Journal of Education and Practice, 8(1), 18-21.

Koca, F. (2016). Motivation to Learn and Teacher-Student Relationship. Journal of International Education and Leadership, 6(2).

La Lopa, J. M., Elsayed, Y. N. M. K., \& Wray, M. L. (2018). The State of Active Learning in the Hospitality Classroom. Journal of Hospitality \& Tourism Education, 30(2), 95-108. https://doi.org/10.1080/10963758.2018.1436971

Liberante, L. (2012). The importance of teacher-student relationships, as explored through the lens of the NSW Quality Teaching Model. Journal of Student Engagement: Education Matters, 2(1), 2-9. Retrieved from http://ro.uow.edu.au/cgi/viewcontent.cgi?article=1008 \&context $=$ jseem

Mabrouk, P. A. (2007). Introduction. In P. Mabrouk (Ed.), Active learning: Models from analytical science: ACS symposium series (pp. 2-13). Washington, DC: American Chemical Society. https://doi.org/10.1021/bk-2007-0970.ch001

Matthews, K. (2016). Students as Partners as the Future of Student Engagement. Student Engagement in Higher Education Journal, 1(1), 1-5.

McCarthy, J. P., \& Anderson, L. (2000). Active learning techniques versus traditional teaching styles: Two experiments from history and political science. Innovative Higher Education, 24, 279-294. https://doi.org/10.1023/B:IHIE.0000047415.48495.05

McPartland, C. (2018). Synergy in Learning, Teachers and Student Support Assistants Working Together to Promote Learner Metacognition in Post-Compulsory Education. Teaching in Lifelong Learning, 8(2). https://doi.org/10.5920/till.537 
Mpakirtzis, K. (2012). Education of preschool students in experiential teaching methods and its effect on their educational practices. Educational Research, 54, 150-168.

Mukeredzi, T. G. (2017). Mentoring in a Cohort Model of Practicum: Mentors and Preservice Teachers' Experiences in a Rural South African School. SAGE Open, 7(2), 1-15. https://doi.org/10.1177/2158244017709863

Murillo-Zamorano, L. R., López-Sánchez, J. Á., \& Godoy-Caballero, A. L. (2019). How the flipped classroom affects knowledge, skills, and engagement in higher education: Effects on students' satisfaction. Computers \& Education, 141, 103608. https://doi.org/10.1016/ j.compedu.2019.103608

Niemi, H. (2002). Active learning-a cultural change needed in teacher education and schools. Teaching and Teacher Education, 18(7), 763-780. https://doi.org/10.1016/S0742-051X (02)00042-2

Nyumba, T. O., Wilson, K., Derrick. J. C., \& Mukherjee, N. (2018). The use of focus group discussion methodology: Insights from two decades of application in conservation. Methods in Ecology and Evolution, 9(1), 20-32. https://doi.org/10.1111/2041-210X. 12860

Ott, L. E., Carpenter, T. S., Hamilton, D. S., \& LaCourse, W. R. (2018). Discovery Learning: Development of a Unique Active Learning Environment for Introductory Chemistry. Journal of the Scholarship of Teaching and Learning, 18(4), 161-180. https://doi.org/ 10.14434/josotl.v18i4.23112

Parsons, L. (2005). Bullied teacher bullied student: How to recognise the bullying culture in your school and what to do about it. Ontario: Pembrook Press.

Philips, J. M. (2005). Strategies for active learning in online continuing education. Journal of Continuing Education in Nursing, 36(2), 77-83. https://doi.org/10.3928/0022-012420050301-08

Rabiee, F. (2004). Focus-group interview and data analysis. Proceedings of the Nutrition Society, 63(4), 655-660. https://doi.org/10.1079/PNS2004399

Ralston, P. A. S., Tretter, T. R., \& Kendall-Brown, M. (2017). Implementing Collaborative Learning across the Engineering Curriculum. Journal of the Scholarship of Teaching and Learning, 17(3), 89-108. https://doi.org/10.14434/v17i3.21323

Sahin-Taskin, C. (2018). Effects of active learning environments supported with self- and peer assessment on pre-service teachers' pedagogical and self-efficacy beliefs, Asia-Pacific Journal of Teacher Education, 46(5), 421-440. https://doi.org/10.1080/1359866X.2017. 1355049

Sánchez-Martin, J., Cañada-Cañada, F., \& Dávila-Acedo, M. A. (2018). Emotional responses to innovative science teaching methods: Acquiring emotional data in a general science teacher education class. Journal of Technology and Science Education, 8(4), 346-359. https://doi.org/10.3926/jotse.408 
Slavich, G. M., \& Zimbardo, P. G. (2012). Transformational Teaching: Theoretical Underpinnings, Basic Principles, and Core Methods. Educational Psychology Review, 24(4), 569-608. https://doi.org/10.1007/s10648-012-9199-6

Strelan, P., Osborn, A., \& Palmer, E. (2020). The flipped classroom: A meta-analysis of effects on student performance across disciplines and education levels. Educational Research Review, 30, 100314. https://doi.org/10.1016/j.edurev.2020.100314

Tanwar, P. (2015). Are we ready for constructivist classroom? A field experience. Indian Journal of Applied Research, 5(8), 78-80. https://doi.org/10.36106/ijar

Taylor, L., \& Parsons, J. (2011). Improving Student Engagement. Current Issues in Education, 14(1), 88 .

Taylor, P. C., \& Wallace, J. (2007). Contemporary qualitative research: Exemplars for science and mathematics educators. Dordrecht, The Netherlands: Springer.

Timmermans, S., \& Tavory, I. (2012). Theory Construction in Qualitative Research: From Grounded Theory to Abductive Analysis. Sociological Theory, 30(3), 167-186. https://doi.org/10.1177/0735275112457914

Tracy, S. J. (2013). Qualitative research methods: Collecting evidence, crafting analysis, communicating impact. West Sussex, UK: Wiley-Blackwell.

Trinidad, J. E. (2020). Understanding student-centred learning in higher education: students' and teachers' perceptions, challenges, and cognitive gaps. Journal of Further and Higher Education, 44(8), 1013-1023. https://doi.org/10.1080/0309877X.2019.1636214

Ulger, K. (2018). The Effect of Problem-Based Learning on the Creative Thinking and Critical Thinking Disposition of Students in Visual Arts Education. Interdisciplinary Journal of Problem-Based Learning, 12(1). https://doi.org/10.7771/1541-5015.1649

Williams, M. (2008). The tower of bloom: Modeling constructionism and active learning in preservice teacher education classrooms. Humanities \& Social Sciences Papers. Retrieved from http://works.bepress.com/marian_williams/2

Yilmaz, M. (2017). Evaluation of pre-service teachers' communication skills. European Journal of Education Studies, 3(5), 326-338. https://doi.org/10.46827/ejes.v0i0.668

Zamora-Polo, F., Corrales-Serrano, M., Sánchez-Martín, J., \& Espejo-Antúnez. L. (2019). Nonscientific University Students Training in General Science Using an Active-Learning Merged Pedagogy: Gamification in a Flipped Classroom. Education Sciences, 9(4), 297. https://doi.org/10.3390/educsci9040297

Zheng, L., Yang, J., Cheng, W., \& Huang, R. (2014). Emerging Approaches for Supporting Easy, Engaged and Effective Collaborative Learning. Journal of King Saud University-Computer and Information Sciences, 26(1), 11-16. https://doi.org/10.1016/ j.jksuci.2013.10.002 


\section{Copyright Disclaimer}

Copyright for this article is retained by the author(s), with first publication rights granted to the journal.

This is an open-access article distributed under the terms and conditions of the Creative Commons Attribution license (http://creativecommons.org/licenses/by/3.0/). 